\title{
Treatment of acute pandysautonomia with intravenous immunoglobulin
}

\author{
Robert A Mericle, William J Triggs
}

\begin{abstract}
Acute pandysautonomia has been suggested to be an uncommon variant of Guillain-Barré syndrome. Acute pandysautonomia does not seem to have been treated with intravenous immunoglobulin or other therapies proved efficacious in Guillain-Barré syndrome. A patient is reported with severe acute pandysautonomia who responded dramatically to intravenous immunoglobulin. The findings are consistent with a dysimmune pathogenesis for this syndrome and suggest a possible treatment for future cases.
\end{abstract}

$(F$ Neurol Neurosurg Psychiatry 1997;62:529-531)

Keywords: acute pandysautonomia; intravenous immunoglobulin; autonomic nervous system disease

Acute pandysautonomia was first described by Young et al in 1969. ${ }^{1}$ Since this time, 27 cases have been reported. ${ }^{1-24}$ The disorder presents with clinical features reminiscent of the autonomic failure of severe Guillain-Barré syndrome, including severe orthostasis, impairment of gastrointestinal motility and bladder function, impotence, impairment of pupillary reactivity and accommodation, and dryness of the eyes, nasopharynx, and skin. ${ }^{25-27}$ Recovery occurs slowly and is often incomplete. Commonly, patients are left with disabling residual symptoms.8 ${ }^{8} 1315171924$

Similarity between acute pandysautonomia and the autonomic failure of severe GuillainBarré syndrome suggests that acute pandysautonomia may be an uncommon variant of Guillain-Barré syndrome. ${ }^{1346812141517192025}$ This hypothesised relation is strengthened by the existence of cases of acute pandysautonomia with varying degrees of sensory loss and dysaesthesiae..$^{51516}$ Raised CSF protein in many cases of acute pandysautonomia is also consistent with this hypothesis. ${ }^{27}$

Little is known regarding the treatment of acute pandysautonomia. Corticosteroids have been given with disappointing mixed results. ${ }^{1791519202327}$ More recently, one patient with acute pandysautonomia was treated symptomatically with $400 \mathrm{mg}$ L-threo-3,4dihydroxyphenylserine (L-DOPS) daily. ${ }^{21}$
This patient required daily symptomatic treatment for more than two years. To our knowledge, however, treatment of acute pandysautonomia with therapies proved efficacious in Guillain-Barré syndrome ${ }^{28-31}$ has not been reported. We hypothesised that acute pandysautonomia would respond to treatment with intravenous immunoglobulin (IVIg).

\section{Case report}

PRESENTATION

A previously healthy 26 year old woman was admitted to hospital at the University of Florida Health Science Center in November of 1994 with severe acute pandysautonomia. Four weeks earlier, she had developed a generalised rash while receiving trimethoprim/sulfamethoxazole for treatment of a urinary tract infection. She presented with a clinical syndrome characterised by orthostasis, syncope, abdominal pain, anorexia, nausea, vomiting, photophobia, dryness of her mouth, eyes, and skin, diarrhoea, and incontinence of stool. She also complained of burning dysaesthesiae in her feet. Evaluation at an outside hospital disclosed severe orthostatic hypotension without secondary tachycardia, due to absent responses to baroreceptors. One blood pressure recording was $130 / 70 \mathrm{~mm} \mathrm{Hg}$ while supine and it dropped to $50 / 0 \mathrm{~mm} \mathrm{Hg}$ while standing. Normal laboratory studies included renal and liver functions, complete blood count, erythrocyte sedimentation rate, antinuclear antibodies, serological testing for syphilis, and porphyrins. There were no cells in the CSF; CSF protein was $78 \mathrm{mg} / \mathrm{dl}$ and glucose $75 \mathrm{mg} / \mathrm{dl}$. Abdominal CT, a rectal biopsy, nerve conduction studies, and EMG were all normal. An upper gastrointestinal series disclosed pooling of barium in the stomach and much increased transit time. The patient was then transferred to our institution. She had no history of travel, botulism, exposure to toxins, medications, or infections other than that previously mentioned. Family history was negative, and there was no evidence of Adie's, RileyDay, or Shy-Drager syndromes.

\section{EXAMINATION}

Examination showed a photophobic young woman lying supine. On sitting upright, her blood pressure fell from $110 / 70$ to $40 / 0 \mathrm{~mm}$ and in revised form

Accepted 23 January 1997 
$\mathrm{Hg}$ and she lost consciousness transiently. Although she lost peripheral pulses, her heart rate remained stable during hypotension (105 bpm supine, $110 \mathrm{bpm}$ standing). Her mouth, pharynx, and skin were very dry. Higher cortical functions were intact. Her pupils were $5 \mathrm{~mm}$ bilaterally and unreactive to light or accommodation. Motor examination was normal. Sensory examination was notable for severe hyperaesthesia in the patient's feet. Deep tendon reflexes were normal.

A "cold pressor test" was performed by submerging the patient's hands into a large bucket of ice water for 60 seconds. This test was abnormal, with an absent rise in blood pressure. Nerve conduction studies and concentric needle EMG were normal. The sympathetic skin response ${ }^{32}$ was absent. A nuclear medicine gastric emptying study showed very reduced gastric emptying with no appreciable response to metoclopramide. ECG telemetry for eight days showed no sign of dysautonomic arrhythmia.

\section{TREATMENT}

Intravenous immunoglobulin (IVIg) was given on days $1,2,3,5$, and 8 at a dose of $0.4 \mathrm{~g} / \mathrm{kg} /$ day. Clinical improvement was obvious by day 3 in both subjective and objective measurements. Pupillary responses returned, now constricting from $5 \mathrm{~mm}$ to $3 \mathrm{~mm}$ bilaterally. This was accompanied by resolution of her photophobia. Her orthostasis improved and she regained heart rate responses to baroreceptors; she was now capable of developing tachycardia in the face of hypotension (supine blood pressure 125/82 $\mathrm{mm} \mathrm{Hg}$, heart rate $88 \mathrm{bpm}$; standing blood pressure $82 /$ $42 \mathrm{~mm} \mathrm{Hg}$, heart rate $126 \mathrm{bpm}$ ). She reported resolution of postural lightheadedness. Her mouth and pharynx became moist and sweat appeared on her skin. The incontinence

Previously reported cases of acute pandysautonomice

\begin{tabular}{lll}
\hline Case No & $\begin{array}{l}\text { Time until recovery } \\
\text { (months) }\end{array}$ & Authors \\
\hline 1 & 18 & Young et al $1969^{1}$ \\
2 & 28 & Andersen et al $1972^{2}$ \\
3 & 192 & Apenzeller and Kornfeld $1973^{3}$ \\
4 & 6 & Bost et al $1983^{4}$ \\
5 & 18 & Colan et al $1980^{5}$ \\
6 & 9 & Cortelli et al $1990^{6}$ \\
7 & 60 & Ducla-Soares et al $1993^{7}$ \\
8 & No recovery/death & \\
& at 36 months & Fagius et al $1983^{8}$ \\
9 & 12 & Feldman et al $1991^{9}$ \\
10 & 24 & Goulon et al $1971^{10}$ \\
11 & 9 & Guidi et al $1981^{11}$ \\
12 & 10 & Hart and Kanter $1990^{12}$ \\
13 & No mention of recovery & Hirayama $1989^{13}$ \\
14 & 4 & Hopkins et al $1974^{14}$ \\
15 & 48 & Hopkins et al $1974^{14}$ \\
16 & 60 & Low et al $1983^{15}$ \\
17 & No recovery & Low et al $1983^{15}$ \\
18 & 31 & Okada et al $1975^{16}$ \\
19 & 11 & Okada et al $1975^{16}$ \\
20 & No mention of recovery & Sannomiya et al $1989^{17}$ \\
21 & 12 & Sekine et al $1991^{18}$ \\
22 & No recovery / death & Stoll et al $1991^{19}$ \\
23 & 24 & Thomashefsky et al $1972^{20}$ \\
24 & 24 (but temporary improvement & Ushiyama et al $1996^{21}$ \\
25 & with daily L-DOPS & Wichser et al $1972^{22}$ \\
26 & 6 & Yahr and Frontera $1975^{23}$ \\
27 & No recovery at 72 months & Yee et al $1976^{24}$ \\
28 & 15 days & Mericle and Triggs 1997 \\
& & our patient \\
\hline & &
\end{tabular}

Mean (SD) recovery time was 30 (39) months. resolved. On days 4,6 , and 7 , in between IVIg treatments, we noted transient worsening of dysaesthesiae. The dysaesthesiae had disappeared by the completion of IVIg treatment. Nausea and anorexia resolved over the next few weeks. The patient was discharged after 16 days in hospital. On follow up over one year later, examination was notable only for milder, asymptomatic orthostatic hypotension (supine blood pressure $117 / 78 \mathrm{~mm} \mathrm{Hg}$, heart rate $85 \mathrm{bpm}$; standing blood pressure 104/ $62 \mathrm{~mm} \mathrm{Hg}$, heart rate $98 \mathrm{bpm}$ ). She was living independently with no complaints and no symptoms.

\section{Discussion}

This patient showed dramatic improvement of acute pandysautonomia temporally associated with administration of IVIg. It is conceivable that symptomatic improvement in our patient was merely coincident with the IVIg. Indeed, spontaneous resolution of acute pandysautonomia is not infrequent. ${ }^{1-79-12} 14-161820-23$ However, our analysis of previously reported cases (table) showed that recovery from this condition is usually protracted and incomplete. Partial recovery in previously reported cases of acute pandysautonomia occurred after an average of 30 months and residual disability was not uncommon. By contrast, our patient improved rapidly after receiving IVIg and recovered much more quickly than previously reported cases. Given the natural history of acute pandysautonomia, we suggest that improvement in our patient was not spontaneous, but was likely related to administration of IVIg.

To our knowledge, this case represents the first time that acute pandysautonomia has been treated with therapy proved efficacious in Guillain-Barré syndrome. ${ }^{28-31}$ Plasma exchange is associated with various medical complications, including hypotension and cardiac arrhythmia. ${ }^{33-34}$ Intuitively, plasma exchange imposes an even greater risk of these complications in patients with severe dysautonomia. By contrast, administration of IVIg in this setting probably poses considerably less risk. The extremely low incidence of acute pandysautonomia makes a clinical trial of treatment of this disorder unlikely. However, our findings suggest that acute pandysautonomia is in fact a variant of Guillain-Barré syndrome. We suggest that early treatment of IVIg deserves consideration in cases of this syndrome.

We have no commercial or proprietary interest in the items discussed in this manuscript

1 Young RR, Asbury AK, Adams RD, Corbett JL. Pure pandysautonomia with recovery. Transactions of the American Neurological Association 1969;94:355-7.

2 Andersen O, Lindberg J, Modigh, Rese-Nielsen E. Subacute dysautonomia with incomplete recovery. Acta Neurol Scand 1972;48:510-9.

3 Appenzeller O, Kornfeld M. Acute pandysautonomia. Arch Neurol 1973;29:334-9.

4 Bost M, Rossignol AM, Tachker D, Batellier H, Jeannoel $P$. A case of acute reversible dysautonomia in an adolescent. Pediatrics 1983;38:29-36.

5 Colan RV, Snead OC, Oh SJ, Kashlan MB. Acute autonomic and sensory neuropathy. Ann Neurol 1980;8 441-4.

6 Cortelli P, Contin M, Lugaresi A, Baruzzi A, Montaga P. 
Severe dysautonomic onset of Guillain-Barré syndrome with good recovery. A clinical and autonomic follow-up study. Ital f Neurol Sci 1990;11:159-62.

7 Ducla-Soares JL, Guerreiro AS, Povoa P, Alvares E, Guerreiro L, Carrilho F, et al. Pure autonomic failure. Acta Med Port 1993;6:533-7.

8 Fagius J, Westerberg CE, Olsson Y. Acute pandysautonomia and severe sensory deficit with poor recovery. A clinical, neurophysiological, and pathological case study. $\mathcal{F}$ Neurol Neurosurg Psychiatry 1983;46:725-33.

9 Feldman EL, Bromberg MB, Blaivas M, Junck L. Acute pandysautonomic neuropathy. Neurology 1991;41:746-8.

10 Goulon $M$, Nouailhat F, Grosbuiss S, Gajdos P. Hypotension orthostatique à pouls invariable: étude hypotension orthostatique a pouls invariable: etude idiopathique transitoire. Rev Neurol (Paris) 1971;125: 257-72.

11 Guidi L, Zeppilli P, Sassara M, and Ghirlanda G. Cardiovascular autonomic impairment in one case of acute pandysautonomia with recovery. G Ital Cardiol 1981;11: 1151-9.

12 Hart RG, Kanter MC. Acute autonomic neuropathy. Two cases and a clinical review. Arch Intern Med 1990;150: 2373-6.

13 Hirayama $\mathrm{K}$. Acute curable pandysautonomia and chronic progressive pandysautonomia. Bulletins of the Osaka Medical Collage 1989;35:113-7.

14 Hopkins A, Neville B, Bannister R. Autonomic neuropathy of acute onset. Lancet 1974;i:769-71.

15 Low PA, Dyck PJ, Lambert EH, Briminjion WS, Trautmann JC, Malagelada JR, et al. Acute panauto-

16 Okada F, Yamashita I, Suwa N. Two cases of acute pandysautonomia. Arch Neurol 1975;32:146-51.

17 Sannomiya K, Kudo Y, Mori T, Nakazato O, Okajima T. A case of acute idiopathic pandysautonomia. Rinsho Shinkeigaku 1989;29:895-900.

18 Sekine $T$, Tateyama $M$, Saito $H$. A case of subacute idiopathic pure pan-dysautonomia-recovery with prednisolone therapy. Rinsho Shinkeigaku 1991;31:445-50.

19 Stoll G, Thomas C, Reiners K, Schober R, Hartung HP. Encephalo-myelo-radiculo-ganglionitis presenting as pandysautonomia. Neurology 1991;41:723-6.

20 Thomashefsky AF, Horwithz SF, Feingold MH. Acute autonomic neuropathy. Neurology 1972;22:251-5.

21 Ushiyama M, Ikeda SI, Suzuki T, Yazawa M, Yanagisawa
N, Tsujino SI. Acute pandysautonomia: mass spectrometric and histopathological studies of the sympathetic nervous system during long term L-threo-3,4-dihydroxyphenylserine treatment. If Neurol Neurosurg Psychiatry 1996;61:99-102.

22 Wichser J, Vijayan N, Dreyfus PM. Dysautonomia: its significance in neurologic disease. Calif Med 1972;117: 28-37.

23 Yahr MD, Frontera AT. Acute autonomic neuropathy: its occurrence in mononucleosis. Arch Neurol 1975;32. $132-3$

24 Yee RD, Trese $M$, Zee DS, Kollarits CR, Cogan DG Ocular manifestations of acute pandysautonomia. $A m^{f}$ Ophthalmol 1976;81:740-4.

25 Lichtenfeld P. Autonomic dysfunction in the GuillainBarré syndrome. Am $\mathcal{F}$ Med 1971;50:772-80.

26 Young RR, Asbury AK, Corbett $\mathrm{J}$, Adams RD. Pure pandysautonomia with recovery. Brain 1975;98:613-36.

27 Ropper AH, Wijdicks EFM, Truax BT. Guillain-Barré syndrome. Philadelphia: FA Davis, 1991

28 Osterman PO, Fagius J, Lundemo G, et al. Beneficial effects of plasma exchange in acute inflammatory polyradiculoneuropathy. Lancet $1984 ;$;i: 1296-9.

29 Guillain-Barré Syndrome Study Group. Plasmapheresis and acute Guillain-Barré syndrome. Neurology 1985;35: 1096-104.

30 French Cooperative Group on Plasma Exchange in Guillain-Barré syndrome. Efficiency of plasma exchange in Guillain-Barré syndrome: role of replacement fluids. Ann Neurol 1987;22:753-61.

31 Van der Meché FG, Schmitz PI. A randomized trial comparing intravenous immune globulin and plasma Barré Study Group. N Engl f Med 1992;326:1123-9.

32 Shahani BT, Day TJ. Cros D, Khalil N, Kneebone CS. RR interval variation and the sympathetic skin response in the assessment of autonomic function in peripheral neuropathy. Arch Neurol 1990;47:659-64.

33 Bouget J, Chevret S, Chastang C, Raphael JC. Plasma exchange morbidity in Guillain-Barré syndrome: results from the French prospective, double-blind, randomized, multicenter study. The French Cooperative Group. Crit Care Med 1993;21:651-8.

34 Thornton CA, Griggs RC. Plasma exchange and intravenous immunoglobulin treatment of neuromuscular disease. Ann Neurol 1994;35:260-8. 